\title{
MEDICAL WASTE MANAGEMENT AND MINIMIZATION EFFORTS AT PUBLIC HOSPITAL. CASE STUDY: PUBLIC HOSPITAL IN EAST JAKARTA, INDONESIA
}

\author{
Puri Wulandari ${ }^{1}$, Haryoto Kusnoputranto ${ }^{2}$ \\ ${ }^{1}$ Master Student in Faculty of Public Health, University of Indonesia \\ ${ }^{2}$ Professor in Environmental Health Faculty of Public Health, University of Indonesia \\ Email: purichan.wulandari@gmail.com
}

\begin{abstract}
Background: Medical waste is classified as hazardous waste and toxic materials. Equipped with various health facilities and visited by 1,267 people/day and occupancy rate is 68 percent in 2011, Public Hospital in East Jakarta generates a large number of medical wastes. Although medical waste generated less than domestic waste but potentially major cause of occupational accidents and illnesses transmission if not managed properly. This research aims to know how the hospital minimize and process the medical waste.

Method: Research methodology used in this research is qualitative approach from the aspect of the characteristics, effort minimization and management of medical waste. This research also used quantitative method by calculating the medical waste based on the occupancy rate and the service given.

Results: The results showed that the generation of medical waste as much as 0.9 pounds/ patient.days with 64 percent occupancy rate, while based on the type of service that is at most of the operating room of 0.67 pounds/ patient.days. Medical waste minimization efforts that have been done of segregation, housekeeping, preventive maintenance, clean technology, substitution of materials, and management of chemical and pharmaceutical, whereas only limited efforts to use waste reuse.

Conclusion: The conclusion of this research was the minimization efforts do not do recycling and recovery, whereas the management of medical waste is not eligible especially separation, transport, storage, and management of ash from incineration of medical waste.
\end{abstract}

Keywords: avian influenza, behavior, adjacent area

\section{Introduction}

Medical waste is classified as hazardous and toxic waste with code D227. ${ }^{1}$ The waste including medical waste, among other infectious waste, pathology, sharps, pharmaceutical, cytotoxic, chemical, radioactive, pressurized containers, and waste containing heavy metals high. ${ }^{2}$

Medical waste generated from health services only 10 to $25 \%$ only, while the remaining $75-90 \%$ of waste generated by domestik. ${ }^{3}$ Although the amount of medical waste generated less than that of domestic waste, but has great potential in the medical waste poses a risk of accidents labor and disease transmission if not handled with good. ${ }^{4}$ According to WHO (1999), the average production of hospital waste in developing countries ranges from $1-3 \mathrm{~kg} / \mathrm{bed}$. day, whereas in developed countries such as Europe and the United States reached $5-8 \mathrm{~kg} /$ bed. Day. ${ }^{5}$ In 2003 , generation of medical waste from the hospital around $0.14 \mathrm{~kg} / \mathrm{bed}$. day, with a composition of $80 \%$ non-infectious waste, $15 \%$ of pathology and infectious waste, $1 \%$ sharps, $3 \%$ of waste chemicals \& pharmaceuticals, $>1 \%$ tube and thermometer broke. ${ }^{6}$

An important element in the management of hospital waste, namely waste minimization, segregation, collection, transportation, storage, removal and disposal. ${ }^{7}$ Efforts a top priority is the minimization of waste in the form of waste reduction at the 
source and waste utilization. ${ }^{8}$ Waste reduction at the source is an attempt to decrease the volume, concentration, toxicity, and hazard level of waste to be spread in the environment, is preventive directly on the sources of pollution. Waste utilization is an effort to reduce the volume, concentration, toxicity, clan level of danger that spread in the environment, by means of use by means of reuse, recycle, recovery. In Developing Countries, medical waste has not received special attention was dumped together with domestic waste. ${ }^{9}$ Results WHO assessment conducted in 22 developing countries showed that the proportion of health care facilities that do not use proper waste disposal methods ranges from $18 \%$ to $64 \%{ }^{10}$

However, so far the hospital's medical waste management in Indonesia is still below professional standards have not been entirely correct and safe. ${ }^{11}$ In 2009, research activities in 6 hospital (in Medan, Bandung and Makassar) showed that $65 \%$ of hospitals have done sorting between waste medical and domestic waste (plastic bags of yellow and black), but still common one place and by $65 \%$ Public Hospital has incinerators with combustion temperatures between $530-800^{\circ} \mathrm{C}$, but only $75 \%$ are functioning. Processing of incinerator ash has not performed well. In addition, there is no accurate information generation medical waste because $98 \%$ of hospitals have not keep records of medical waste. ${ }^{6}$

Public Hospital in East Jakarta is one of our hospitals with type B+. Based on the results of the medical record in 2010 , bed occupancy rate (BOR) of $68 \%$, while the number of outpatients of 500 people/ day. Given this hospital is currently experiencing an increase in the number of beds for an increase of $15 \%$, the number of employees by $5 \%$, and an increase in bed occupancy rate and the number of outpatient visits. With occupancy patient loads and also the type of health services provided by the hospital, then the amount of medical waste generated is also great.

\section{Research Method}

This research was a quantitative and qualitative study with a descriptive approach. Selection techniques informant by purposive sampling based on the principles of suitability and adequacy acquired 11 people who are the parties involved in waste management. Qualitative data analysis with triangulation of sources and methods is observation, interviews, and review documents. Quantitative data analysis with:

a. Calculations based on BOR:

$$
\text { Medical waste generation }=\frac{\text { total production of medical waste }}{\text { Bed Occupancy Rate }}
$$

b. Calculations based on the type of service:

$$
\text { Medical waste generation }=\frac{\text { average daily production of medical waste }(\mathrm{kg})}{\text { average patients per day }}
$$

\section{Results and Analysis}

\section{A. Characteristics of Medical Waste}

Units that become a source of infectious waste that is inpatient, outpatient clinic, surgery room, maternity room, emergency room, ICU, laboratory, hemodialysis. Pathological waste generated by the surgery room, maternity room, and laboratories. The following table 1 observations and interviews regarding the sources and types of medical waste generated by public hospitals.

KESMAS Vol. 9, No. 2, September 2015: $77-84$ 
Table 1. Medical Waste by Source Type

\begin{tabular}{|c|c|}
\hline Source & Medical Waste by Source Type \\
\hline Inpatient & $\begin{array}{l}\text { Hypodermic needles, syringes, IV tubes, plabot infusion, flacon, catheters, } \\
\text { gauze former, catheters, handscoen / disposable gloves, disposable masks, } \\
\text { disposable blood lancet, bottles / ampoules of drugs, dressings former, cotton / } \\
\text { gauze / cloth with blood or body fluids, blood transfusion hose, former bandage, } \\
\text { alcohol swab.. }\end{array}$ \\
\hline Polyclinic & $\begin{array}{l}\text { Hypodermic needles, syringes, gauze, disposable gloves,, disposable masks, } \\
\text { packs / bottles of medicine, cotton / gauze / cloth exposed to blood or body } \\
\text { fluids, Pasteur pipette and sticks. }\end{array}$ \\
\hline Surgery room & $\begin{array}{l}\text { sarung tangan disposable, masker disposable, jarum suntik, spuit, selang infus, } \\
\text { infusion bottles, surgical gloves, catheters, scalpels damaged body tissues, } \\
\text { blood bags, chemicals, yarn operations, gauze former body fluid / blood. }\end{array}$ \\
\hline Maternity room & $\begin{array}{l}\text { bottles, surgical gloves, catheters, scalpels damaged body tissues, blood bags, } \\
\text { chemicals, yarn operations, gauze former body fluid / blood. }\end{array}$ \\
\hline $\begin{array}{l}\text { Emergency } \\
\text { room }\end{array}$ & $\begin{array}{l}\text { Hypodermic needles, syringes, IV tubes, infusion bottles, catheters, disposable } \\
\text { gloves, disposable masks, bottles / ampoules of drugs, dressings former, gauze, } \\
\text { cotton / gauze / cloth with blood or body fluids. }\end{array}$ \\
\hline ICU & $\begin{array}{l}\text { Hypodermic needles, syringes, IV tubes, infusion bottles, catheters, disposable } \\
\text { gloves, disposable masks, bottles / ampoules of drugs. }\end{array}$ \\
\hline Laboratory & $\begin{array}{l}\text { syringe, sputum pot, pot urine / feces, reagents, chemicals, glass slides, serum, } \\
\text { cotton, filter paper, disposable masks, disposable gloves, yellow tip, swab the } \\
\text { former, alcohol swabs, serum cup, ose inoculum, disposable petri dish, } \\
\text { autoclave bags, specimen containers / former preparations of the activities of } \\
\text { pathology, anatomy }\end{array}$ \\
\hline Pharmacy & $\begin{array}{l}\text { Expired drugs (tablets, capsules, syrups, injections, ointments, creams) that can } \\
\text { not be returned to the manufacturer, the rest of the concoction of drugs, drugs } \\
\text { such as syrup unused / eye drops were not sealed, creams / ointments that are } \\
\text { not stored in a tube which is not sealed. }\end{array}$ \\
\hline Hemodialysis & Bottle $\mathrm{NaCl}$, various sharp objects such as syringes, blood bags, HD set \\
\hline Radiology & $\mathrm{S}$ \\
\hline
\end{tabular}

Pharmaceutical waste generated by the pharmacy, while the sharps waste generated almost all sources except pharmacies. Radioactive waste is generated in radiology unit in the form of liquid fixer and developer and managed by third parties.

Based on the calculation of the amount of medical waste recapitulation of data obtained an average generation of medical waste generated $\pm 72 \mathrm{~kg} / \mathrm{day}$. To determine the average generation of medical waste from each source can be seen in Table 2.

Table 2. Average Medical Waste Generation Based on Service Type

\begin{tabular}{lccc}
\hline \multicolumn{1}{c}{ Service Type } & $\begin{array}{c}\text { Average daily medical } \\
\text { waste }(\mathrm{kg})\end{array}$ & $\begin{array}{c}\text { The average } \\
\text { patient/ day }\end{array}$ & $\begin{array}{c}\text { Generation } \\
\text { (kg/patient.day) }\end{array}$ \\
\hline Polyclinic & 4,13 & 383 & 0,01 \\
Surgery room & 11,83 & 6 & 0,67 \\
Maternity room & 3,65 & 6 & 0,6 \\
Emergency room & 6,3 & 64 & 0,1 \\
Laboratory & 3,27 & 118 & 0,03 \\
Hemodialysis & 7,5 & 14 & 0,5 \\
Radiology & 3,45 & 48 & 0,07 \\
$\quad$ Total & 40,13 & 639 & 1,98 \\
\hline
\end{tabular}

For the calculation of medical waste generation by the bed occupancy rate (BOR) as follows: 
a. $\mathrm{BOR}=64 \%$ with the number of beds 204

$$
\begin{aligned}
\text { BOR } & =\frac{64}{100} \times 204 \text { bed } \\
& =131 \mathrm{bed} / \text { day }
\end{aligned}
$$

b. Medical waste generation

$$
\begin{aligned}
\text { Medical waste generation } & =\frac{\text { total production of medical waste }}{\text { BOR }} \\
& =\frac{118,7 \mathrm{~kg}}{131 \mathrm{bed} / \mathrm{day}}=0,9 \mathrm{~kg} / \mathrm{bed} . \text { day }
\end{aligned}
$$

Sources of medical waste generation at most that the inpatient unit is 0.9 $\mathrm{kg} / \mathrm{bed}$.day with a $64 \%$ bed occupancy rate. This is similar to previous research, which says that a lot of medical waste generated in the treatment room pasien. ${ }^{12}$ Factors affecting the amount of waste generated is the bed occupancy rate and the type of health services diberikan. ${ }^{13}$ Bed occupancy rate (BOR) Public Hospital for $64 \%$. The bed occupancy rate including standard ideal because according to the Ministry of Health level ideal bed occupancy rate is between $60-80 \%{ }^{14}$

\section{B. Medical Waste Minimization Efforts}

Activities of medical waste reduction at the source that has done public hospital and are in accordance with the Regulation of the environmental impact control agency, among others, segregation, housekeeping, preventive

\begin{tabular}{|c|c|c|}
\hline No & Source & Reduce \\
\hline 1 & $\begin{array}{l}\text { Inpatient, Polyclinic, ICU, emergency } \\
\text { room, medical rehabilitation }\end{array}$ & Segregation \\
\hline 2 & Surgery room & housekeeping, preventive \\
\hline 3 & Maternity room & Segregation, preventive maintenance \\
\hline 4 & Laboratory & Segregation, housekeeping \\
\hline 5 & Pharmacy & $\begin{array}{l}\text { Segregation, material management, returns } \\
\text { to distributor }\end{array}$ \\
\hline 6 & Hemodialysis & housekeeping, \\
\hline 7 & Radiology & Segregation, clean technology \\
\hline
\end{tabular}
maintenance, clean technology, management of chemical and pharmaceutical preparations, and substituting material. ${ }^{8}$

Table 3. Medical Waste Reduction On Source

Based on the above table it can be seen that the reduction in resources has been carried out in almost every source of medical waste that is doing segregation is sorting between medical waste, non-medical, and sharp objects. Medical waste put into yellow plastic bags, non-medical waste into black plastic bags and sharps waste into jerrycans. Preventive maintenance which includes the provision of a new incinerator, incinerator burner service periodically ie every 6 months. In addition, also performed maintenance on the trash to be cleaned using a disinfectant every night. Procurement of transport equipment such as carts to transport all the waste both medical and non-medical. Housekeeping do 
to prevent spills, spills, and contamination of medical waste. Efforts utilization of waste in the form of reuse (reuse) only to the diagnostic equipment made of stainless steel alone previously performed sterilization and disinfectant. This is because most of the materials or tools using disposable equipment. The new waste minimization efforts implemented in Hemodialysis unit including reuse of the former Hemodialysis jerry cans to collect waste sharps and dialyzer reuse previously done washing 4 times, then sterilized and reused after being put Renalin fluid for 11 hours. Management of materials such as chemicals management preparations such as reducing the use of chemicals that could potentially be hazardous waste since the process of planning the purchase and procurement of materials, ordering medication as needed, check the expiration date of drugs. Substitution of materials which use materials that are safe for the user and environmentally friendly use of renalin instead of formalin is used for liquid disinfectant dialyzer, because renalin friendly to the environment. The return to the distributor of drugs is due in large numbers sought may be returned to the distributor for the previous three months. Radiological waste using clean technologies that do not generate waste in the form of fixer and developer, so that the waste generated only syringe.

Utilization of medical waste is carried out in a public hospital in east jakarta only limited reuse. Recycling has not been done because for recycling options are limited by factors such as regulatory restrictions, fears of contamination of infectious agents which may occur in recycled materials, quality control issues, and costs associated with sorting materials recycling as well as the cost of shipping and processing of these materials to third parties. For the utilization of medical waste in the form of recovery is not done. The effort associated with radiology which already have sophisticated tools that do not capture silver in the fixer fluid for medical waste in the form of fixer and developer are no longer produced.

Table 4. Utilization of Waste Through Reuse

\begin{tabular}{ll}
\hline \multicolumn{1}{c}{ Source } & \multicolumn{1}{c}{ Reuse } \\
\hline Hemodialysis & jerry former dialysis solution is used for sharps waste containers \\
Pharmacy & chemicals such as disinfectants used to clean the floor and garbage \\
& other chemicals such as acids, bases, chemical reagents offered to potential \\
Laboratory such as laboratories & $\begin{array}{l}\text { users } \\
\text { containers can be reused after disinfection and sterilization as a petri dish, } \\
\text { glass cups, measuring cups, test tubes, glass desk, glass objects, test tube, } \\
\text { sample cup colonical }\end{array}$ \\
\hline
\end{tabular}

Based on Table 4 it can be seen that the reuse of medical waste that has great potential to provide benefits that the use of jerry cans former hemodialysis, because with these jerry hospitals do not have to buy safety box to accommodate medical waste sharps and suitable to accommodate the waste because it is made of resistant material leak, anti-puncture, and closed.

\section{Medical Waste Management Efforts}

Segregation is not in accordance with Decree 1204 of 2004 the health minister for the chemical and pharmaceutical waste accommodated in a yellow plastic bag and labeling only include details of medical waste. The waste is supposed to use plastic bags brown.

The use of jerry cans hemodialysis former activity has been worthy of the container to accommodate medical waste sharps because according to the WHO criteria that should be in the collection syringe and puncture-resistant containers 
leak-proof, as well as a secure container tertutup. ${ }^{7}$ Use can reduce the risk of needlestick injuries by $80 \%{ }^{15}$ Although already provided three separate containers with plastic bags of different colors. However, in practice still found in medical waste disposal is not in place. Never found a syringe in a yellow plastic bag. It is very dangerous for the safety of workers who handle cleaning service and mainly waste incinerators officer.

In addition, there are nurses who perform the closing syringe (recapping) prior to disposal. Recapping needles should be avoided because it is a very dangerous action and great risk needlestick injuries if not done with care hati. ${ }^{15}$ Epidemiological studies have shown that people who experience one needlestick injuries that have been contaminated would have a risk of becoming infected with $\mathrm{HBV}, \mathrm{HCV}$ and HIV respectively $30 \%, 1.8 \%$, and $0.3 \% .{ }^{10}$ In most cases, the main reason of medical waste management is the absence of proper regulation, the lack of specialized clinical staff, lack of awareness and control that efektif. ${ }^{16}$

Transporting waste is still not in accordance with Decree 1204 of 2004 the health minister using trolley that is not insulated and sealed so that medical and non-medical waste can be mixed. Medical waste transport path using the elevator service, which is also used for the activities of hospital personnel. According to the $\mathrm{WHO}$, if transport using the elevator, it is advisable not to use the same elevator to lift patients/ visitors/ food in waste transportation medis. ${ }^{7}$ Therefore, the transport of medical waste arranged his schedule to be transported to temporary storage of medical waste, so it does not coincide/ overlap with schedule delivery of food and clean linen on the same track.

Medical waste storage must follow the standard building materials storage of hazardous waste based on Government Regulation 18 Jonctu 85 of 1999 . The existence of a temporary storage area serves to prevent the transmission by air, direct contact, or through animals. ${ }^{10}$ Temporary storage area to store medical waste the general hospital has been separated by non-medical waste. However, the temporary storage of medical waste was left open, but already equipped with doors. In addition, the lack of supervision of the temporary storage area so that no unauthorized persons can easily get into the storage area while the medical waste.

The burning of medical waste by incineration can reduce the amount of medical waste until $91-97 \% .{ }^{17}$ In addition, it can change the characteristics and composition composition of hazardous and toxic waste to eliminate and reduce the hazardous properties of the waste. In practice, before the waste incinerator was added to the segregation carried over to plabot infusion, because nearly $80 \%$ of medical waste containing fluid infusion plabot form. This is due to the lack of coordination to do reuse.

Table 5. Comparison of Medical Waste Generated and Burned

\begin{tabular}{ccc}
\hline Month & $\begin{array}{c}\text { Medical waste is generated } \\
(\mathrm{kg})\end{array}$ & $\begin{array}{c}\text { Medical waste is burned } \\
(\mathrm{kg})\end{array}$ \\
\hline January & 2674 & 2532 \\
February & 2424 & 2142 \\
Total & 5098 & 4674 \\
\hline
\end{tabular}

Based on the above Table 5, it can be seen that the amount of medical waste burned is reduced by $8.3 \%$. This is due to the re segresasi can reduce the amount of medical waste to be removal. According to the Minister of environment, plabot infusion uncontaminated hazardous and toxic waste or infectious waste can be recycled. ${ }^{18}$ 
Plabot infusion which is plastic waste, which have increased along with the increasing use of medical objects disposable. ${ }^{19}$ Therefore, the potential for recycling because it is based on research results which are found in the waste incinerator that is plabot infusion. In addition, there is a re-sorting of the plabot infusion before burning. If the infusion plabot that have not been contaminated inserted into black plastic bags during sorting at source will reduce the amount of medical waste to be burnt and can save diesel fuel.

However, the utilization of medical waste in the form of recycling has not been done because the recycling options are limited by factors such as fears of contamination of infectious agents which may occur in recycled materials, quality control issues, and the cost of shipping and processing of these materials to third parties.

Medical waste segregation activities over a very risky activity that cause disease because the waste is mixed with other medical waste and must contain bacteria and viruses that can harm human health, especially the officer incinerator when not using personal protective equipment (PPE). One of the characteristics of the waste suitable for incineration that the water content of less than $30 \% .^{3}$ Plabot segregation infusion aimed at eliminating the water content of the waste. So when the combustion does not take long that the fuel used is not too much. If conditions are very wet waste and contain a lot of water it is necessary to fuel an enormous amount just to evaporate the water and this is a waste costs. ${ }^{2}$

Combustion is done using temperature $1000-1200^{\circ} \mathrm{C}$ for $2-3$ hours. This is evident from incinerator emissions test results showing that no parameter that exceeds quality standards. If the combustion temperature $<1000^{\circ} \mathrm{C}$, means incomplete combustion, and will produce emissions such as $\mathrm{CO}$ and the most dangerous is the formation of dioxins and furans compound is a chemical compound that is colorless and odorless but highly beracun. ${ }^{20}$ Time incineration of medical waste in the form of ash. The ash is then inserted into black plastic bags and placed in a temporary storage area non-medical waste/domestic.

\section{Conclusion}

a. Source of medical waste originating from health care unit which includes Inpatient, polyclinics, surgery room, emergency room, maternity room, ICU, Laboratory, Medical Rehabilitation, Haemodialysis, Radiology, and Pharmacy.

b. Types of medical waste generated includes infectious waste, sharps waste, pathological waste, chemical waste and pharmaceutical waste.

c. Medical waste generation is $0.9 \mathrm{~kg} /$ bed.day with a $64 \%$ occupancy rate, while based on the type of service that is at most of the operating room $0.67 \mathrm{~kg} /$ patient. Day.

d. Medical waste minimization efforts being applied by Public Hospital namely reduction at source, while the utilization of waste only limited reuse. This is because most of the source of medical waste has been using disposable equipment, so that no materials that can be reused.

e. The management of medical waste has not run optimally there are still some things that need to be fixed such as sorting and transport is not in accordance with in 1204 the health minister's decision of 2004. Storage is not in accordance with Government regulations 18 Jonctu 85 of 1999. The destruction of medical waste by using incinerators are in accordance with in 1204 the health minister's decision of 2004. 


\section{References}

1. Peraturan Pemerintah No. 18 Jo PP 85 Tahun 1999 Tentang Pengelolaan Limbah Berbahaya dan Beracun (B3).

2. Departemen Kesehatan RI, Pedoman Pelaksanaan Pengelolaan Limbah Padat dan Limbah Cair di Rumah Sakit, Jakarta: Direktorat Jenderal PPM \& PPL dan Direktorat Jenderal Pelayanan Medik, 2006.

3. Prüss, A., Giroult, E., Rushbrook, P., Pengelolaan Aman Limbah Layanan Kesehatan (Penerjemah: Munaya Fauziah, Mulia Sugiarti, \& Ela Laelasari), Jakarta, EGC, 2005.

4. Massrouje, H. T. N., Medical waste and health workers in Gaza governorates, Eastern Mediterranean Health Journal, vol/no: 7(6), pp. 1017-1024, 2001. http://easternhealth.journal/7/6/1017-1024, diakses 6 Oktober 2011.

5. WHO, Waste Management Guidelines, Geneva, Switzerland, 1999.

6. Ditjen PP \& PL, Kebijakan Kesehatan Lingkungan Dalam Pengelolaan Limbah Medis, 2011.

7. WHO, Management of Solid Health Care Waste at Primary Health Care Centres, Geneva, WHO, 2005.

8. Environmental Impact Control Agency, Guidelines For Waste Minimization, Jakarta, Environmental Impact Control Agency, 1992.

9. Da Silva, C. E., et al., Medical wastes management in the south of Brazil, Waste $\begin{array}{lllll}\text { Management, } & \text { vol/no: } \quad 6 & \text { (25), } & \text { pp. } & 600-605,\end{array}$ http://www.bvsde.paho.org/bvsacd/cd43/mello.pdf, diakses 3 Oktober 2011.

10. WHO, Health-care waste management, 2004. http://www.who.int/mediacentre/factsheets/fs281/en/, diakses 7 Oktober, 2011.

11. Suryandari, Siswantini, Pengolahan Limbah Medis belum Berstandar, Media Indonesia, pp. 20, 2010.

12. Bassey, B. E., Benka-Coker, M. O., Aluyi, H. S. A., Characterization and management of solid medical wastes in the Federal Capital Territory, Abuja Nigeria, African Health Sciences, $\quad$ vol/no: $1(6), \quad$ pp. 2006. http://www.ncbi.nlm.nih.gov/pmc/articles/PMC1831969/pdf/AFHS0601-0059.pdf, diakses 7 Oktober 2011.

13. Askarian, M., Vakili, M., Kabir, G., Results of a hospital waste survey in private hospitals in Fars province, Iran, Waste management, vol. 24, pp. 347-352, 2004. http://www.ncbi.nlm.nih.gov/pubmed/15081061, diakses 12 Oktober 2011.

14. Kepmenkes Nomor 1204/ Menkes/ SK/ X/ 2004 tentang Persyaratan Kesehatan Lingkungan Rumah Sakit, Jakarta, Direktorat Penyehatan Lingkungan, 2004.

15. Wilburn, S. Q., Eijkemans, G., Preventing Needlestick Injuries Among Healthcare Workers, A WHO-ICN Collaboration, 2004. http://www.who.int/occupational_health/activities/5prevent.pdf, diakses 6 Oktober, 2011.

16. Hossain, M. S., et al., Clinical Solid Waste Management Practices and Its Impact on Human Health and Environment--A Review, Waste Management, vol/no: 31(4), pp. 754-66, 2011.http://www.ncbi.nlm.nih.gov/pubmed/21186116, diakses 8 Desember 2011.

17. Rau, E. R., et al., Minimization and Management of Wastes from Biomedical Research, Environmental Health Perspectives, vol. 6, pp. 108, 2000.

18. Kementerian Negara Lingkungan Hidup. Pengelolaan Bahan dan Limbah Berbahaya dan Beracun, Limbah Rumah Sakit, 2006. http://b3.menlh.go.id/pengelolaan/article.php?article_id=95, diakses 6 Oktober 2011.

19. Gil Jong Oh, Status and Challenges of Medical Waste Management in Korea, Ministry of Environment, 2006. http://www.env.go.jp/recycle/3r/en/asia/02_03-2/06.pdf, diakses 6 Oktober 2011.

20. Yong-Chul Jang, et al., Medical Waste Management in Korea, Journal of Environmental Management, pp. 1-9, 2005. http://www.elsevier.com/locate/jenvman, diakses 11 Oktober 2011. 